This is the peer reviewed version of the following article: Kitchen, Veronica and Kim Rygiel. (2014) Privatizing Security, Securitizing Policing: The Case of the G20 in Toronto, Canada. International Political Sociology, doi:10.1111/ips.12052, which has been published in final form at https://doi.org/10.1111/ips.12052. This article may be used for non-commercial purposes in accordance with Wiley Terms and Conditions for Use of Self-Archived Versions.

\title{
Privatizing Security, Securitizing Policing: The Case of the G20 in Toronto, Canada
}

\author{
VERONICA KitCHEN AND Kim RYgIEL
}

\section{Balsillie School of International Affairs}

\begin{abstract}
Allegations of police brutality, unlawful detention, and other breaches of civil liberties during the G20 in Toronto in June 2010 provide an important case through which to understand the changing nature of security and policing, raising questions about the political implications of such shifts in terms of police accountability, transparency and democracy. Within the field of public policing, scholars predicted that globalization processes would weaken public policing as a dominant policing institution. Instead, it has expanded, in part, through the convergence of internal and international dimensions of security, whereby new policy networks cooperate in matters of policing and security in a new integrated model, the result of which is a further militarization of urban space and expanded markets for security that lead to the securitization of everyday life. This article examines the case of Toronto's hosting of the G20 and the role that the Integrated Security Unit played, led by the RCMP and which included private security firms. By focusing on the role of multilateral networks that include private sector actors, we examine the implications of privatization and securitization of policing for democracy, citizenship, and accountability and how they affect the ability of publics to engage in public debate, consult, or protest policies.
\end{abstract}

\section{Introduction $^{1}$}

The dominant images that emerged from the G20 Meeting in Toronto in June, 2010 were not the traditional family photos of world leaders coming together to advance their global initiatives, but rather those of street protests and violence in the context of a massive security operation and allegations of police brutality, unlawful detention, and other breaches of civil liberties (Malleson and Wachsmuth 2011). Such scenes make the Toronto G20 an important case through which to understand the changing nature of security, particularly in the post $9 / 11$ period in which the market for security has grown, and for understanding the implications of a series of shifts in authority and governance for the nature of democracy and the urban citizen.

Since the end of the Cold War, and more particularly since 9/11, scholars have observed that the distinction between inside and outside in international relations has blurred. As part of this transformation, within the area of security studies, Didier Bigo (2011) argues that the domains of internal policing and external defence are no longer separable, but instead merge into one another as part of a "Möbius ribbon" of security networks. In this context, ideas about the meaning of security and the identities of enemies are no longer clear. Similarly, security objectives, mission and guidelines are less certain. As Bigo explains "The boundaries of the security tasks are not fixed through a clear belief of what security is (and what it is not). They [the security agencies and agents] don't know where the inside ends and where the outside begins. They don't know where security is beginning and where insecurity is finishing"

\footnotetext{
${ }^{1}$ We would like to thank John Zelenbaba, Rhys Machold, and Jesse Maclean who provided research assistance for this paper.
} 
(Malleson and Wachsmuth 2011, 113). The möbius ribbon is thus a metaphor for the emergence of an "insecurity continuum" connecting "fear of crime, unemployment, foreigners, drug trafficking and war" (Malleson and Wachsmuth 2011, 113). In the case of the G20, this "insecurity continuum" enabled different security, intelligence and policing agencies - the "professionals in the management of unease" (Bigo 2001) - to work together, coordinated as part of Integrated Security Units, to prevent possible security threats from an unknown enemy. Among these professionals are police officers who are generating for themselves a broader and more flexible mandate for national security policing that is based on a model that integrates them more closely with other parts of the security bureaucracy (Murphy 2007). Within this context of an "insecurity continuum", then, the domains of internal policing and external defence are no longer as distinct as they once were.

An important part of this shifting security governance is the inclusion of private security actors.The privatization of security and the significant role played today by private security companies (PSCs) have increased significantly from the days when former US President Eisenhower warned in his 1961 exit speech of the rise of a "military-industrial complex." PSCs now provide a host of security services including, but not limited to, traditional soldiering, intelligence gathering, strategic planning, disaster relief, border control (Verkuil 2007) and port security (Cowen 2009; Cowen 2010) as well as the provision of security during international mega-events. In recent years, scholarship has drawn our attention to the role now played by private corporations in the provision of military security in particular (Abrahamsen and Williams 2011; Alexandra, Baker, and Caparini 2008; Chesterman and Fisher 2009; Krahmann 2012; Leander 2010). Less attention has been paid, however, to the linkage between the privatization of military services and domestic policing, which has undergone a similar process of privatization (Bayley and Shearing 2001; Murphy 2007). As Christopher Murphy has argued, within the post 9/11 period, the size, resources and mandate of the police has grown as security was made a "policing objective" (Murphy 2007, 8). We argue that the G20 case illustrates how the "securitization of policing" has been compounded by the privatization of security. By securitization, we mean the process by which an issue, practice, or institution comes to be seen through the lens of security or as a threat, where security is itself socially constructed (Buzan, Waever, and De Wilde 1997). The result is expanded markets for security and the further militarization of urban space, that is a "step by step process by which a person or thing...comes to depend for its well-being on militaristic ideas" (Enloe 2000, 3), both of which lead to the greater securitization of everyday life. The G20 case is significant, therefore, for demonstrating how, through the merger between private and public, and domestic and national security, longstanding legal, ethical and political norms and regulations are being re-scripted with significant implications for democratic rights and accountability.

At first glance, studying an event like the G20 as a way of understanding broader security dynamics may seem odd, because the security politics and practices surrounding mega-events are, by definition, exceptional. In part, their exceptionalism is precisely what makes them interesting: how do we rationalize particular kinds of exceptional politics, and not others? (Huysmans 2004; Aradau and van Munster 2009). Mega-events are important here precisely because, through this appeal to exceptionalism, they often serve as testing grounds for the securitization of particular spaces and places and for testing new tactics and technologies, through which the exceptional becomes routinized into the everyday life of cities. Boyle and 
Haggerty argue that mega-events are an opportunity to showcase the power and sovereignty of the city through spectacular displays that promise the unattainable condition of perfect security (Boyle and Haggerty 2009). A mega-event is the perfect opportunity for a city to demonstrate its resilience and (potential) ability to recover from disruptive events or security threats, maximizing its potential for attracting transnational capital (Coaffee and Wood 2006; Boyle 2005). Megaevents are also a market opportunity for police departments to acquire new purchases such as security equipment and technologies and may therefore be catalysts for the further securitization and militarization of cities or what Stephen Graham refers to as "cities under siege" (Graham 2010). What becomes evident from an examination of the G20 Meeting in Toronto (as well as the hosting of other mega-events such as the 2010 Vancouver and 2012 London Olympics) is that cities are increasingly becoming key sites in the marketing of security services and technologies. By examining news reports, briefing notes, emails, police training manuals and reports of public inquiries, we show how governments become not only the providers of security but increasingly consumers of security through the purchase of equipment and services of PSCs. This, in turn, has deep implications for the very way that cities are themselves now made the objects of securitization (Graham 2004) with the objective of shifting the very meaning of the urban experience and citizens" "right to the city" (Lefebvre 1995) towards less democratic forms (Malleson and Wachsmuth 2011).

\section{Privatized security}

The discussion of the "insecurity continuum" and the merger of policing, intelligence and defence networks are compounded by the phenomenon of the privatization of security. International relations scholars have noted for some time now the role of actors other than the state in providing "governance without government" (Rosenau and Czempiel 1992). As Hall and Biersteker (2002) observe, legitimate authority requires some form of public consent on the part of the governed, but, as they are quick to point out, "being public does not, however, imply that a state for public institution must be involved, or be wielding authority." This then "opens the possibility for the emergence of private, non-state based, or non-state legitimated authority and the idea that "authority does not necessarily have to be associated with government institutions" (Hall and Biersteker 2002, 5). Scholars of international public policy and globalization explain this change as a response to neoliberal restructuring of the global economy that has increasingly hollowed out the welfare state and favoured a growth in privatized forms of authority and new public-private partnerships (Scholte 2005; Hall and Biersteker 2002; Boerzel and Risse 2005). Security privatization is part of this more general trend toward the privatization of government in a bid to operate more efficiently. Importantly, as Abrahamsen and Williams note, this kind of privatization should not be seen as a retreat of the state. Rather, private security companies work in concert with the state and often draw their legitimacy partly-although not exclusively - from the state (Abrahamsen and Williams 2007, 238).

Within International Relations, the literature on private security has tended to focus on private military companies (PMCs) employed in war zones rather than on the way that private companies are employed to deliver front-line security in lieu of or in concert with traditional military, police, and intelligence forces. Literature on the role of PMCs points out that, while there may be certain advantages to privatized security (such as, for example, that PMCs may be 
in a better position to fill the "security gap" and deploy better trained and professionalized soldiers), the idea that actors like PMCs provide increased public security is a "conclusion (that) can only be reached if the dynamics of the market for force are neglected" (Leander 2005a, 605). Private security and military companies have an "epistemic power" (Leander 2005b, 803) through which they are able to shape the meaning of security, the security problems and preferences and influence choices about the actors required to resolve the problems. They do so often in ways that justify their own roles and budgets (Leander 2005a). This proliferation of private security actors indicates a shift towards not only security that is "privatised but also remilitarised" (Leander 2005b, 804).

On the domestic front, private security, in particular, has significantly increased as states have cut back public services such as public policing (Lippert and O'Connor 2003, 333). The popular doctrine of resilience shifts the burden of security to society (Chandler 2013) and helps to justify the use of private security organizations. Private security actors and individuals become important actors in the provision of security, rather than merely referent objects to be protected. Thus as Lippert and O'Connor have argued (2003, 334), “Once a right of citizenship or public good, physical security is said to be becoming more and more a commodity bought and sold in the marketplace; that is, increasingly consumed, rather than exercised as a right." Within this context, "the public sector is increasingly a consumer (rather than a producer) of security services" (Lippert and O'Connor 2003, 334). Referring to the work of Shearing and Stenning (1981) Lippert and O'Connor argue that "the growth of private security [is] a 'quiet revolution' that coincides with the expansion and spread of 'mass private property,' such as shopping malls, office, recreational, industrial, and manufacturing complexes. It is argued that an increasing share of public life takes place on such privately owned and governed properties" (Lippert and O'Connor 2003, 334) or what Rigakos and Greener (2000) call private "bubbles of governance". In other words, what we see here, as Deborah Cowen $(2010,602)$ has argued, is the way that "market rationalities [are] at the center of the production of space." The "territorial limit" that was the "official basis for the division between police and military force and between crime and terror," and which also "forged 'domestic' legal space" (Cowen 2010, 602) is challenged, on the one hand, by the privatization of national security and the military, and on the other hand, through the increasing privatization and re-militarization of domestic security and the police. The G20 becomes an excellent case in point that shows this blurring of inside/outside space and security networks but also shows not accidently how a key location of this blurring is the city.

Studying the privatization of security in the context of policing at the G20 illustrates not only how policing itself has become more securitized or militarized, and how enforcement practices adopt military tactics, but also reveals how cities have become the key testing grounds for military tactics and weaponry in recent years (Coaffee 2004). One of the significant implications of the merger of internal and external security networks that has resulted in the securitization of policing is the way in which the idea of waging war somewhere else has shifted to a sense that conflict and war might need to be fought right here on the homefront. Stephen Graham refers to this as the city as "battlespace" (Graham 2009) or "the idea of 'asymmetric' war as the key security idea among nation states, militaries and corporations. Here, rather than war with other states, the main challenge for states is deemed to be mobilising more or less permanently against vague non-state or civilian threats that lurk within their own cities and the infrastructures that connect them" (Graham 2012). 
This idea that "security is coming home" (Coaffee and Wood 2006) shapes cities in particular ways. As geographers like Susan Bickford point out, "the paradigmatic characteristic of cities is that they are places where strangers regularly encounter one another in a variety of social spaces, including 'at one's own doorstep"' (Bickford 2000, 357). Cities are often, in other words, spaces that facilitate the encounter with diverse and possibly uncertain - even risky - perspectives and ways of being. But this "reciprocal dynamic of urban securitization" or the "urbanization of security," as Coward $(2009,399)$ calls it, in which "the security agenda is urbanized and urbanity is insofar as it induces insecurity and vulnerability-securitized" has particular implications for cities. As many scholars have argued, the forms of border controls normally experienced at the external borders of the state (such as identity checks and surveillance measures) become increasingly diffused throughout the domestic sphere, concentrating within cities. Thus the "coming home" of security and the continued emphasis on societal resilience is also about extending surveillance and security measures normally reserved for the border to circulate and seek out the stranger within. The urbanization of security has a particular impact, therefore, on certain groups of people, such as multiethnic and im/migrant groups, who find themselves becoming particular targets of security measures within the city (Thobani 2004). In addition, the hosting of mega-events in the city provides openings for the securitization of policing and the privatization of security within the city that is related to the larger trend of an increasing privatization of public space. But more than simply the privatization of public space, as previously discussed by Shearing and Stenning (1981) this trend is about the "purification" of both private and public space, that is "to purify them of fear, discomfort, or uncertainty" in ways that enact deep segregation in cities (Bickford 2000, 357). Events such as the criminalization of dissent in Toronto during the G20 summit in June 2010 speak to the ways in which the city noted for such characteristics as density, diversity and publicity - that is as a space of politics of dissent, where people are forced to contend with those who think differently than they do-is under attack. Securing the city, then, is about much more than security in the city if it transforms the very experience of what it means to live in urban space, and the nature of democratic accountability.

\section{The G20 Meeting in Toronto: The Role of Private Security Companies}

With international security "coming home", cities have come to be conceptualized as part of the global security dynamics and this has opened up new possibilities for applying the techniques of military security to the urban setting (Graham 2010). Thus, the hosting of mega-events has become big business for cities. Not only do they bring in a host of foreign delegates, diplomats and their support staff, along with the press corps, but they also become sites of tourism and marketing of cities on the international stage (Black 2007; Boyle 2005). As Louise Comfort at the University of Pittsburgh noted before the event, "It's a big opportunity for international visibility, and Toronto needs to show that it's a grown-up international city and it can handle this" (Agrell and Paperny 2010).

A look at the Government of Canada's budget for hosting the G8/G20 shows just how big a market for hosting such mega-events in cities has become. The hosting of an event like the G20 presents an extremely lucrative security market. Stephen Graham notes that "ramping up" security and surveillance "is thus now as much a part of economic policy as a response to 
purported threats" (Graham 2012). According to the G8 Information Centre at the University of Toronto, the G8 and G20 were expected to generate nearly $\$ 400 \mathrm{M}$ in benefits to the economies of Toronto and Ontario (Guebert and Tanna 2010). From the beginning, government authorities budgeted amounts far higher for security than had been spent at previous G20 summits. While security costs were ultimately under budget, they were still much higher than at other Summits. The Pittsburgh 2009 summit had security costs of US\$98.7 million and London's Summit in 2009 cost US $\$ 28.6$ million for security (Kirton, Guebert, and Tanna 2010). The Auditor General of Canada's 2011 report estimates that the total costs spent were $\$ 664 \mathrm{M}$. However, another report to the Standing Committee on Public Safety and National Security puts this total amount closer to $\$ 790 \mathrm{M}$ and breaks down this higher figure as follows: $\$ 507.5 \mathrm{M}$ for the RCMP's policing and security budget; $\$ 278.3 \mathrm{M}$ for Public Safety; $\$ 3.1 \mathrm{M}$ for the Canadian Security Intelligence Service; and finally, \$1.2M for the Canada Border Services Agency (Sorenson 2011, 5). In addition to this, there are the costs associated with the post-Summit inquiries into the fallout of the G20. For example, an independent civilian review of the G20 requested by the Toronto Police Services Board was projected to cost \$1M (McKiernan 2012). This was only one of 9 inquiries into the aftermath of the G20.

A significant portion of those costs were spent to hire private security providers, to purchase security apparatus from private companies, or to secure spaces of the city for exclusive access by certain group - all aspects of the privatization of security. While the RCMP's share of security costs came under budget, due to a smaller than anticipated RCMP deployment (6228 rather than 7041 officers), competitive procurement, and the fact that the RCMP held the government's $\$ 60 \mathrm{M} \mathrm{G8/G20} \mathrm{contingency} \mathrm{fund} \mathrm{(Treasury} \mathrm{Board} \mathrm{of} \mathrm{Canada} \mathrm{2011),} \mathrm{private} \mathrm{security} \mathrm{costs} \mathrm{were}$ unexpectedly high. In explaining the unexpected high costs for private security, the budget report notes, "private security firms were used more extensively than initially planned thus reducing the requirement for police personnel" (RCMP 2010; Shearing and Stenning 1981, 4). In an internal report filed by the RCMP to the Government of Canada further breaks down RCMP expenditures on security noting that $\$ 32.5 \mathrm{M}$ was spent on private security personnel, including the Corps of Commissionaires (RCMP 2010, 2). The RCMP budget also included $\$ 15.1 \mathrm{M}$ to cover the costs of Fencing and Perimeter Intrusion Detection Systems, with another $\$ 8.3 \mathrm{M}$ devoted to information technology equipment (RCMP 2010, 2). Finally, \$33.9M was spent on Command Centers and Other Real Property Costs including "a Unified Command Center fit-up and equipped in Barrie as well Area Command centers established for the G8 and G20 in Huntsville and Toronto, respectively" along with other "operational facilities" that were "acquired and fitup" (Ibid., 4).

Toronto Police Services generated a worst-case scenario budget, based on a short six-month planning horizon, of $\$ 144.4 \mathrm{M}$, which helps to explain why final claims submitted were $38.2 \%$ below this budget (Toronto Police Services Board 2011). The discrepancy can be further explained by the fact that the federal and provincial governments funded many of the incremental costs associated with hosting the G20 on short notice, in addition to the G7/8, as well as subsidizing equipment costs (Stancu 2010) - the TPS ultimately paid $\$ 2.3 \mathrm{M}$ for equipment it retained at $50 \%$ of its cost. .

Summit security costs covered the employment of several private contractors to provide a range of services. According to (Freeze 2010), federal contract tenders included private consultants 
used for communications and planning and evaluating a training exercise. For example, emails exchanged within the Privy Council Office make it clear that Orion Consulting Services, a strategic communications service, was hired to help the government transmit its preferred message to diverse stakeholders. Orion Consulting drafted talking points for various purposes and speeches for Ward Elcock, the Co-ordinator for Olympic and G8/G20 security in the Privy Council Office ("PCO Emails (G20 Papers Batch 2, PCO, Documents PCO-01, PCO-03, \& PCO-04)" 2010). With respect to training exercises, Public Safety Canada hired a consultant, Moreau Emergency Management Consulting Corporation, to evaluate Exercise Trillium Guardian, a training exercise for the G8/G20 (Moreau Emergency Management Consulting Corp and Public Safety Canada 2010). Interestingly, Moreau Emergency Management is owned and operated by Richard Moreau, who, according to his Linked-in profile, has since been hired directly by Public Safety Canada in its Interoperability Development Office (Moreau n.d.).

Finally, Olivus Incorporated was paid $\$ 5480.00$ in a non-competitive bid for "Training" (which, according to according to its website, includes leadership, team building, and conflict and conflict resolution training). Similarly, Peerless Security (Peerless Communications) was awarded \$183 159.54 on a non-competitive bid for "security at OPP Staging Areas" with Peerless' website confirming that they provided direct security in Huntsville area for the G8 (Ontario Provincial Police 2010). Another \$37 913.89 was directed towards the Commissionaires for "Security for OPP Warehouse in Huntsville" (Ontario Provincial Police 2010).

In addition to these examples, private security contractors played roles in three cases, which became politicized, and which demonstrate the blurred lines between war and peace, the urbanization of security, and the securitization of everyday life.

\section{PSCs and Improper Licensing}

The security operations at the G20 and the Vancouver Olympics were linked through the provision of private security by the firm Contemporary Security Canada (CSC). CSC is consortium of three security firms-Aeroguard International of Toronto, Contemporary International of Salt Lake City, and United Protection Services of Edmonton-that won a contract valued at $\$ 94.2 \mathrm{M}$ to provide 5000 security screeners for competition venues, the Athlete's Village, and the media centres during the Vancouver 2010 Olympic Games (Lee 2009). In order to generate enough security screeners for the Olympics in such a short time, the provincial government changed a regulation in September 2009 allowing security guards to be hired on a temporary basis for 90 days without extensive training (Lee 2009). Most security screeners received between 20 and 56 hours of training (Mertl 2010), and news reports indicated that many of the private security screeners would be students from various post-secondary programs in security and communications (Ruskin 2010).

The RCMP hired the same firm to fulfill a contract worth over $\$ 20 \mathrm{M}$ to provide over 1000 security guards to provide security screening functions inside the summit security zone. Controversially, the RCMP hired the firm before it had a license to operate in Ontario. The Government of Ontario fast-tracked the licensing procedure, which normally takes four to six months, to just two weeks so that the firm would have a license before the Summit actually began (McLean 2011). According to competitors licensed in Ontario, CSC offered \$20-\$24 / 
hour for security guards, or approximately twice the average pay in Ontario for a licensed private security guard. According to the Association of Professional Security Agencies, if the contract been tendered for public bidding, a licensed-in-Ontario company could have offered the same services for $\$ 10 \mathrm{M}$ (Warmington 2010). ${ }^{2}$ The RCMP maintain that other firms licensed in Ontario - including G4S, the world's largest security firm, which provided Summit security to the G20s in Pittsburgh and London, as well as the London 2012 Olympics - were ill-equipped or had unsatisfactory references (CBC News Ottawa 2011; Graham 2012). There were some unsubstantiated allegations in the media of improper influence, given that the Vice President of Operations for Aeroguard Security, Terry Smith, is a retired RCMP Officer (Warmington 2010). With the demand for private security guards in Ontario so high, the Ministry of Community Safety \& Corrections was forced to relax some of its regulations covering private security licenses, allowing expired licenses to be extended for 30 days, to "ensure that licensees with imminent expiry dates are able to continue to provide security services at this critical time" (Government of Ontario 2010).

In March, 2011, CSC was charged with "three counts of offering security services while not licensed, two counts of failing to ensure proper uniforms and one charge of hiring an unlicensed guard for the G20 and G8 summits" (CBC News Ottawa 2011). Because it was the RCMP who approached CSC, and not vice versa, all but the first set of charges were dropped. CSC pleaded guilty and was fined \$45 000 (CBC News Ottawa 2011). While the RCMP's transgressions in this case are relatively minor, they do highlight the potential dangers of privatization. The RCMP faced compressed timelines due to the late announcement of the G20 summit, but even so, it is disturbing that the Ontario government had to alter its licensing regulations, even in a minor way, to allow for the private security operation to proceed. Moreover, the allegations of inflated security costs suggest that while the use of private security guards for low-skill screening activities may be cheaper than using police officers, the private market is likely to try to extract all possible profits.

\section{Equipment Purchase and Testing}

Mega-events are a huge opportunity for security marketers. Organizers have virtually unlimited security budgets and a mandate to provide the best possible security for their event. As Stephen Graham notes, in the run-up to the London 2012 Olympic Games, the security industry in the UK saw the Games as a sure bet in difficult economic times (Graham 2012). Governments are equally keen: prior to the Olympics, the Security Industry Authority (SIA), an independent regulatory body which reports to the Home Office, released a fact sheet to prepare businesses to best take advantage of the opportunities afforded by the Games (Security Industry Authority n.d.). It seems clear that, as Graham argues, that "ramping up surveillance is thus now as much a part of economic policy as a response to purported threats" (Graham 2012).

Mega-events are also opportunities for local police departments and other security officials to acquire new technology and equipment, often with little public debate or fanfare, under the guise

\footnotetext{
2 Other security firms hiring private security guards in Ontario during the G20 reportedly paid \$11-\$18 (CBC News.ca 2010). If those figures are accurate, then CSC's pay is high even if we allow for inflated prices during a time of high demand.
} 
of security. The Toronto Police Service was able to keep the equipment it purchased for the G20 at $50 \%$ of its original cost, under the Federal Government's Security Cost Framework Policy and the G20 cost-sharing agreement between TPS and Public Safety. According to a report from the Chief of Police, William Blair, to the Toronto Police Services Board in January, 2011, most of the equipment the Toronto Police Service was routine and benign, including, for instance, IT equipment, furnishings, and interview and booking equipment, to be used to outfit new police facilities already under construction, vehicle equipment, and assorted sundry items such as saws, hammers, and evidence bags. More concerning is the decision to keep 52 of the 71 CCTV cameras purchased from the G20, at a 50\% cost of $\$ 703000$. According to Chief of Police William Blair, the cameras will allow for "the augmentation of the existing cameras to provide further support to the Entertainment District, Yonge Street and focused neighbourhoods and contributes to the CCTV program objectives." The TPS also kept "surveillance equipment" used for "intelligence activities" at a 50\% cost of $\$ 136500$, but did not detail what it was or how the TPS planned to use it after the G20 (Toronto Police Services Board 2011). In light of evidence that CCTV cameras have little deterrent effect on deterring riots or assaults, and that they may not be significantly more effective for prosecuting crimes, this seems like an example of increasing domestic surveillance without any promise of an objective decrease in crime or security threats. ${ }^{3}$

The TPS also kept clothing, equipment, and gas masks sufficient to outfit an additional 100 public order police officers, bringing Toronto's total public order capacity to 400 officers, at a $50 \%$ cost of $\$ 375000.420$ gas masks and carry bags were also purchased for the public order unit, at $50 \%$ cost of $\$ 80500$ (Toronto Police Services Board 2011). Most controversial was the decision to keep four Long-Range Acoustic Devices (LRADs) without a debate from the Police Board, at a 50\% cost of $\$ 30300$ (Doolittle 2011; Toronto Police Services Board 2011). For example, long-range acoustical devices (LRADs) or 'sound cannons' were originally developed by the US military for use against Somali pirates and Iraqi insurgents only to be later tested 'at home' in the space of the city during Pittsburgh's 2009 hosting of the G20. Justifying the use of LRADs, Pittsburgh's police bureau chief stated, "Other law enforcement agencies will be watching to see how it was used. It served its purposes well" (ISU Joint Intelligence Group 2009). A 2009 Intelligence Report on the Pittsburgh G20 noted that the LRADs, designed by the military and used against Iraqi insurgents and Somali pirates, were used for the first time by police against protesters "to emit a high pitched sound that forced demonstrators to cover their ears and withdraw" (ISU Joint Intelligence Group 2009, 001493). The report adds, without editorial comment, "there were no reports of demonstrators attending the hospital" (ISU Joint Intelligence Group 2009, 001493). However as Deborah Cowen and Neil Smith document, "the LRAD is designed to induce nausea, vomiting, and abdominal pain. At its highest volume it can cause human bones to resonate. It can be used to deliver thunderous crowd control commands in public space or switched to an elevated 'alert' function which delivers high-pitched ear piercing blasts measuring as high as 135-155 decibels. The generally accepted upper limit of safe noise in 85 decibels above which ear damage is likely" (Cowen and Smith 2010, 38). Presumably cognizant of this reputation of the LRADs, another briefing (G8/G20 Integrated Security Unit 2010 , 115) corrected previous references to the LRAD as a "non-lethal weapon", referring to it

\footnotetext{
${ }^{3}$ A 2009 London Metropolitan Police study suggested that only one crime was solved for every 1000 cameras, often because evidence was not admissible in court. The study also suggested that CCTV is most effective for deterring property crime (Hope 2009)
} 
instead as a "communications device." The acquisition of the LRADs was controversial from the beginning, with the RCMP distancing itself from the Toronto Police's idea of using them for crowd control (CTV News 2010). ${ }^{4}$ It is therefore not surprising that the Toronto Police's decision to keep the LRADs was controversial. The Chief of Police reported that two of the LRADs would go to the public safety unit, one to the marine unit, and one to Toronto Fire Services. His report to the Police Services Board argued that "the LRAD systems are a benefit not only in communicating to the public but also as a means of communicating with emergency personnel when existing communication systems fail or are overwhelmed." Without explicitly mentioning the controversy, he further reported that "the Public Safety Unit has also engaged with scientists at the National Research Council to determine models that might assist in the safe usage and deployment of the LRAD systems. These steps will help the Service to move forward with the use of these tools in a safe and effective manner" (Toronto Police Services Board 2011).

Even with these promises to use only the loud-hailing capacity of the device (and not its sonic canon), sociologist David Murakami-Wood points to the precedent of the Taser as an example of how owned capacity can become "function creep"-with the Taser now being used routinely by police departments (CTV News 2010). The G20 was clearly an opportunity for the Toronto Police to acquire equipment that give it new domestic security capabilities at no cost to itself. As the report to the Police Board indicates, the TPS retained equipment worth $\$ 2.3 \mathrm{M}$ under the $50 \%$ cost sharing agreement. $\$ 1.7 \mathrm{M}$ of this equipment was covered by the reimbursement of the full costs of TPS officers seconded to the G8/G20 planning team that TPS received from Public Safety. The remaining $\$ 600000$ came from various TPS capital projects that had already been budgeted for (Toronto Police Services Board 2011). Therefore, there was essentially no extra cost to the TPS for equipment acquired during the G20; in fact, they saved money. Thus the G20 provides an opportunity for security marketers to get their goods into the hands of security providers, and for police to acquire products they could not otherwise justify. The result is the increased militarization of urban spaces, often without public consultation.

\section{The Security Fence}

In addition to this equipment and testing, the privatization of security played out through the very direct control and privatization of space at the G20. As at most mega-events, security was organized in concentric rings or "rings of steel" (Coaffee and Wood 2006; Coaffee 2004). As Coaffee and Wood explain, these security zones "have been enacted on a permanent basis around 'at risk' sites or temporarily to restrict access to vulnerable sites at certain times, for example at high-profile sporting fixtures, cultural festivals or political meetings. The underlying aim of such a security infrastructure is to give those inside the hermetically sealed zone a feeling of safety, territorial definition and a representation of high security" (Coaffee and Wood 2006, 505). In the case of the G20, the convention centre and hotels where delegates were to stay were the most directly controlled, with very restricted access for summit attendees and employees only. Within these zones, a particular image of Ontario was projected to Summit delegates, most famously through the creation of a "fake lake" inside the Direct Energy Centre's G20 media zone, where journalists could relax without having to travel to an actual lake, or venture outside the privatized space of the securitized zone (Rider 2010).

\footnotetext{
${ }^{4}$ The RCMP stated that it only supported the use of LRADs for maritime operations (CTV News 2010).
} 
A high fence surrounded an outer security perimeter, and beyond that a "traffic zone" of regulation and exclusion extended from Spadina Ave. to Yonge St., and from King St. to Lake Ontario (Kennedy and Mclean 2010). Residents of the area (including one residential building located inside the security fence) were encouraged to sign up for identification cards which would allow them expedited access to their homes - and the Toronto Police even promised to erase the personal information two days after the Summit, rather than keeping it for a year as allowed by law (CBC News Toronto 2010). Reilly Security also hired 120 extra workers to provide security at condominiums, businesses, and buildings in the "traffic zone", separately from the publicly funded deployments (CBC News.ca 2010). Elsewhere in the city, Canadian Civil Liberties Association Monitors reported that police were stopping and searching citizens far away from the exclusion zone. For example, in Leslieville, near the Toronto Police detention centre, grocery stores were closed for the day and individuals living in the area were stopped and searched at random. Those without identification were prevented from returning home. Residents were given no prior warning that this is what they should expect if they left home for the day. ${ }^{5}$ It really did seem that the City of Toronto had become "Fortress Toronto", as the media had taken to calling it (Aulakh 2010; Yang 2010a).

By far the most controversial measure for the control of public space was the security fence. The original tender was for a one-to-two kilometer fence, but by the time it was completed by SNCLavalin, the fence stretched more than six kilometers and supposedly cost approximately $\$ 5.5$ million (Agrell 2010). However, correspondence between the Privy Council Office of the Prime Minster and the consulting company overseeing fence security, suggests that costs had actually doubled. In an email to Cara Thomson of ORION Consulting Services, Trevor Zack of the PCO seeks confirmation regarding media inquiries about costs and states "I am seeking your input/okay on this content. My concerns: (1) whether the $\$ 5.4$ million figure has been disclosed publically, and (2) whether you are comfortable with the messaging on how the budget has risen to $\$ 9.4$ million" (Zack 2010) .

The fence became a symbol of what was seen to be an excessive security operation that had little regard for the rights of citizens to move freely about their city. In fact, as several protestors were told by police that day" "You have no rights here today" (quoted in Cowen and Smith 2010, 37). The security fence is therefore an example of how multilateral networks employ private security companies (used to secure the perimeter defined by the fence) and the privatization of space to control the movement of individuals in the city and therefore shape their access and rights to the city. . The security fence became the center for a controversy over the Public Works Protection Act (PWPA)(Revised Statutes of Ontario 1990), under which two activists were arrested a few days before the Summit. On this occasion and for several more days, the Toronto Police maintained that the arrests were covered by a rule that allowed them to check anyone coming within five metres of the fence for identification. The Act stipulates that a guard or peace officer "may require any person entering or attempting to enter any public work or any approach thereto to furnish his or her name and address, to identify himself or herself and to state the purpose for which he or she desires to enter the public work in writing or otherwise" (Revised Statutes of Ontario 1990, sec. 3.a.). The PWPA also gives power to an official to "search without warrant any person entering or attempting to enter a public work or a vehicle in the charge or under the control of any such person" (Revised Statutes of Ontario 1990, sec. 3.b) and states that officials

\footnotetext{
${ }^{5}$ Personal observations and discussions with residents by one of the authors.
} 
"may refuse permission to any such person to enter a public work and use such force as is necessary to prevent any such person from so entering" (Revised Statutes of Ontario 1990, sec. 3.c). Refusal to comply is an offence subject to a fine or arrest without warrant (Revised Statutes of Ontario 1990, sec. 5.2.). As it turned out, the Premier of Ontario had, on request of police chief Bill Blair, enacted a regulation designating the security zone enclosed by the fence to be a "Public Work" under the PWPA (McMurtry 2011, 12). Until the G20, it had only ever been used to authorize checking identification at courthouses and nuclear facilities (McMurtry 2011, 3-4). The regulation was published on Ontario's e-laws website, but not announced.

The erroneous interpretation of the regulation was widely reported in the media, but neither the police nor the province made any attempt to correct it (Yang 2010b; Radwanski 2010). Interestingly enough, police training manuals, such as that of the Waterloo Regional Police Service, reveal that at the time police officers were being advised to read the Act in detail and were being trained to use the Act. While it is difficult to know exactly what was said during the training course, lecture slides and the accompanying presentation notes suggest that the training may have contributed to the misinterpretation of the act. It is not clear whether the definition of "Public Work" in the act was discussed, but the definition of "highway" was explained like this:

Highway is less specific and generic but is exactly as you believe a highway to be. If the intersection is blocked under the Public Works protection Act you can demand them to identify and ask them to leave for their safety!! (Waterloo Region Police Service 2010, 58-59)

This report of front-line officers receiving legal training, both on the PWPA and relevant sections of the criminal code, could be an example of a tactic Luis Fernandez argues is common in public order policing: police departments tell their officers all the charges they could possibly use to arrest a protester, with what is actually legal only being worked out later, in the courts (Fernandez 2008, 89). This theory gains credence from the fact that over 1100 people were detained during the G20, of which 113 were released immediately without charge, and 714 were arrested and released within 24 hours (The Canadian Press 2010).

A report from Ontario's Ombudsman after the G20 concluded that the regulation under the PWPA was unconstitutional, as the Act was not designed with event security in mind, and that the new regulation should have been publicized more widely (Marin 2010). The official report by Hon. Roy McMurtry to the Ministry of Community Safety and Correctional Services recommended repealing the law entirely and replacing it with something else (McMurtry 2011, 48). In 2012, the PWPA was replaced with new legislation with a narrower mandate covering only power plants and courthouses (Benzie and Talaga 2012).

Monitors sent out by the CCLA reported that police officers stopped and searched individuals "far away from the G20 security perimeter", often at the entrances and exits to subway stations and parks. When asked, the police officers reportedly gave no legal justification for searches, and continued with them even in the absence of clear consent. When justification was given, monitors report that the reasons included "'the city is burning', "we search everyone with a backpack on the way into a protest', and simply 'look at the guy's shirt' referring to a t-shirt that 
read 'F*ck the G-20"' (Canadian Civil Liberties Association 2010, 11). These are examples of de-facto privatization that further securitize the city by controlling the flow of people in, out and throughout the city. This effectively creates new borders within the city, as this kind of control is more usually associated with entry and exit at external, state borders.

\section{Conclusion: Lessons learned?}

The provision of security at the G20 in Toronto in June 2010, and at mega-events more generally, is an important illustration of the way in which the lines of provisions of domestic security through policing and of national security through the military are increasingly becoming blurred, and how privatization facilitates the urbanization and militarization of security. We argue that the G20 case illustrates how policing is increasingly securitized and militarized but also that an important part of this shift is in the way that cities are the 'homefront' of new testing grounds for military weaponry and tactics of war. Equally important to note is the fact that this merger of security networks is the result of a globalizing neoliberal economy in which the security market is rapidly creating transformations in political space with implications for how we conceptualize what it means to be a citizen. Under the guise of resilience, citizens become not merely subjects to be protected, but part of a crowd-sourced effort to implicate citizens in their own protection by privileging certain kinds of behaviours over others - often in conjunction with private companies (Schimmel 2012). Therefore, the provision of security during mega-events like the G20 is not simply a story about the employment of private actors to provide what was formerly a public good - security, in keeping with arguments about the restructuring of modern welfare states under neoliberalism. It is also a story about how markets re-spatialize security from the nation-state and external borders of the state to domestic space within. This, in turn, has implications for the way the city becomes an important site of this transformation. The case of Toronto's G20 draws our attention away from the location of the state to that of the city as an important site of this transformation. Part of the story of the G20 is the way increased militarization is not only fought through the city but is related to what some have called "urbicide" and a war on cities (Campbell, Graham, and Monk 2007; Cowen 2007). Importantly, as Cowen (2007) has noted, there is also a story here about rural/urban relations and the way the "powerful discourse of the rural ideal identifies the rural as the authentic space of patriotic militarism" and denies "the authenticity of the urban, even constituting the city as perverse and unnatural" (Cowen 2007, para. 30). Many commentators, politicians and business owners had questioned the Harper cabinet's sudden decision to move the hosting of the G20 from the outskirts of the city to the city's centre. Moreover, "Even before the G20 arrived, it was widely proposed that Prime Minister Stephen Harper, whose governing conservative party won not a single parliamentary seat in the Toronto metropolitan area was cynically setting the city up" (Cowen and Smith 2010, 44). This is a story, then, that illustrates how hosting mega-events are used, paradoxically, as a way of drawing international recognition to cities to attract global capital, but also how the same reasoning is used to justify inflated security budgets built around expanded security markets that employ public and private security actors to securitize the space for global capital. At the same time, security in the city is used to justify securitization of particular city spaces but also of the city as an idealized form of urban living. It is precisely those aspects of urban living that have made the city an important space for enacting various forms of citizenship (for both those with and without legal status as citizens) - aspects such as encounters with strangers and experiences living with diversity, uncertainty, and difference - which are also 
under attack in the post 9/11 securitization of borders, space and ways of living. This in turn has implications for re-casting the duties of and what it means to be a citizen through everyday living toward more militarized notions of the 'securitized citizen' (Rygiel 2008). The securitized citizen is a reconstitution of the modern, liberal, rights-bearing citizen-subject, a subject constituted no longer as much through rights discourse but increasingly through the language of security and authorization. What cases like the G20 ultimately attest to then is the importance of thinking through the intersection of the privatization of security and the urbanization of war. The challenge and opportunity for critical scholarship now, as Deborah Cowen puts it, "is to think military violence abroad through routine violence at home" (Cowen 2007, para. 4).

\section{References}

Abrahamsen, Rita, and Michael C Williams. 2007. "Securing the City: Private Security Companies and Non-State Authority in Global Governance." International Relations 21 (2): 237-253.

Abrahamsen, Rita, and Michael C. Williams. 2011. Security Beyond the State: Private Security in International Politics. Cambridge University Press.

Agrell, Siri. 2010. "No Mere Barricade - The Globe and Mail." The Globe and Mail, June 22, sec. World. http://www.theglobeandmail.com/news/world/g8-g20/background/no-merebarricade/article1614025/.

Agrell, Siri, and Anna Mehler Paperny. 2010. "Toronto's G20: The Summit of All Fears." The Globe and Mail, February 20.

Alexandra, Andrew, Deane-Peter Baker, and Marina Caparini, ed. 2008. Private Military and Security Companies: Ethics, Policies and Civil-Military Relations. 1st ed. Routledge.

Aradau, Claudia, and Rens van Munster. 2009. "Exceptionalism and the 'War on Terror'." British Journal of Criminology 49 (5): 686-701.

Aulakh, Raveena. 2010. "What to Expect This Weekend in 'Fortress Toronto'." The Toronto Star, June 25. http://www.thestar.com/news/torontog20summit/article/828306--what-toexpect-this-weekend-in-fortress-toronto.

Bayley, David H., and Clifford D. Shearing. 2001. The New Structure of Policing: Description, Conceptualization and Research Agenda. Washington: U.S. Dept. of Justice, Office of Justice Programs, National Institute of Justice.

Benzie, Robert, and Tanya Talaga. 2012. "'Secret' G20 Law to Be Scrapped." The Toronto Star, February 22. http://www.thestar.com/news/canada/politics/article/1135110--secret-g20law-to-be-scrapped.

Bickford, Susan. 2000. "Constructing Inequality: City Spaces and the Architecture of Citizenship." Political Theory 28 (3) (June 1): 355-376.

Bigo, Didier. 2001. "The Mobius Ribbon of Internal and External Security(ies)." In Identities, Borders, Orders: Rethinking International Relations Theory, edited by Mathias Albert, David Jacobson, and Yosef Lapid, 91-116. U of Minnesota Press.

Black, David. 2007. "The Symbolic Politics of Sport Mega-Events: 2010 in Comparative Perspective.” Politikon: South African Journal of Political Studies 34 (3): 261. doi:10.1080/02589340801962536.

Boerzel, Tanja, and Thomas Risse. 2005. "Public-Private Partnerships: Effective and Legitimate Tools of Transnational Governance?” In Complex Sovereignty: Reconstituting Political 
Authority in the Twenty-first Century, edited by Edgar Grande and Louis W. Pauly. University of Toronto Press.

Boyle, Philip. 2005. "Olympian Security Systems: Guarding the Games or Guarding Consumerism?" Journal for the Arts, Sciences and Technology 3 (2): 12-17.

Boyle, Philip, and Kevin D. Haggerty. 2009. "Spectacular Security: Mega-Events and the Security Complex.” International Political Sociology 3 (3): 257-274. doi:10.1111/j.17495687.2009.00075.x.

Buzan, Barry, Ole Waever, and Jaap De Wilde. 1997. Security: A New Framework for Analysis. Lynne Rienner Pub.

Campbell, David, Stephen Graham, and Daniel Bertrand Monk. 2007. "Introduction to Urbicide: The Killing of Cities?" Theory \&amp; Event 10 (2). doi:10.1353/tae.2007.0055. http://muse.jhu.edu/login?auth=0\&type=summary\&url=/journals/theory_and_event/v010 /10.2campbell.html.

Canadian Civil Liberties Association. 2010. “A Breach of the Peace”. Canadian Civil Liberties Association. http://ccla.org/2010/06/29/ccla-releases-a-preliminary-report-ofobservations-during-the-g20-summit/.

CBC News Ottawa. 2011. "G8/G20 Security Firm Fined \$45,000.” October 7. http://www.cbc.ca/news/canada/ottawa/story/2011/10/07/g20-security-firm-fined.html.

CBC News Toronto. 2010. “Toronto Police Will Erase G20 Info.” CBC News Toronto. May 20. http://www.cbc.ca/news/canada/toronto/story/2010/05/20/g20-informationdestroyed542.html.

CBC News.ca. 2010. "So You Want to Be a Summit Security Guard?” CBC. June 3. http://www.cbc.ca/news/canada/story/2010/06/02/f-g20-g8-private-security-jobs.html.

Chandler, David. 2013. "Resilience and the Autotelic Subject: Toward a Critique of the Societalization of Security." International Political Sociology 7 (2): 210-226. doi:10.1111/ips.12018.

Chesterman, Simon, and Angelina Fisher, ed. 2009. Private Security, Public Order: The Outsourcing of Public Services and Its Limits. Oxford University Press.

Coaffee, Jon. 2004. "Rings of Steel, Rings of Concrete and Rings of Confidence: Designing Out Terrorism in Central London Pre and Post September 11th." International Journal of Urban and Regional Research 28 (1) (March 1): 201-211. doi:10.1111/j.03091317.2004.00511.x.

Coaffee, Jon, and David Murakami Wood. 2006. "Security Is Coming Home: Rethinking Scale and Constructing Resilience in the Global Urban Response to Terrorist Risk." International Relations, 20 (4): 503 -517.

Coward, Martin. 2009. "Network-Centric Violence, Critical Infrastructure and the Urbanization of Security." Security Dialogue 40 (4-5) (August 1): 399-418. doi:10.1177/0967010609342879.

Cowen, Deborah. 2010. "A Geography of Logistics: Market Authority and the Security of Supply Chains." Annals of the Association of American Geographers 100 (3): 600-620. doi:10.1080/00045601003794908.

Cowen, Deborah, and Neil Smith. 2010. “"Martial Law in the Streets of Toronto':G20 Security and State Violence" 3 (3): 29-49.

Cowen, Deborah. 2007. "National Soldiers and the War on Cities." Theory \&amp; Event 10 (2). doi:10.1353/tae.2007.0057. 
http://muse.jhu.edu/login?auth=0\&type=summary\&url=/journals/theory_and_event/v010 /10.2cowen.html.

CTV News. 2010. "RCMP, Local Police Deliver Mixed Messages on Security - CTV News." CTV. June 6. http://toronto.ctv.ca/servlet/an/local/CTVNews/20100604/g20-securitymixed-message-100606/20100606/?hub=TorontoNewHome.

Doolittle, Robyn. 2011. "Police Board 'shocked' Force Will Keep Sound Cannons Thestar.com.” Toronto Star, February 3. http://www.thestar.com/news/article/933139-police-board-shocked-force-will-keep-sound-cannons.

Enloe, Cynthia H. 2000. Maneuvers the International Politics of Militarizing Women's Lives. Berkeley, Calif.: University of California Press. http://search.ebscohost.com/login.aspx?direct=true \&scope $=$ site $\& d b=n l e b k \& d b=n l a b k \& A$ $\mathrm{N}=42263$.

Fernandez, Luis A. 2008. Policing Dissent: Social Control and the Anti-globalization Movement. Rutgers University Press.

Freeze, Colin. 2010. "Small Army to Protect Toronto During G20 Summit." The Globe and Mail, April 7, online edition.

http://www.theglobeandmail.com/news/national/toronto/small-army-to-protect-torontoduring-g20-summit/article1525511/.

G8/G20 Integrated Security Unit. 2010. "ISU-GIS Summit 2010 Document ID\#12316, 00079 (Batch 02-RCMP JIG Report-J3551)”. Toronto Media Co-op. http://toronto.mediacoop.ca/story/download-g20-papers/9197.

Government of Ontario, Ministry of Community Safety and Correctional Services. 2010. "Private Securiy and Investigative Services- News and Updates: Amendments to Regulations Under the Private Security and Investigative Services Act, 2005." June 14. http://www.mcscs.jus.gov.on.ca/english/PISG/private_inv_sec.html.

Graham, Stephen, ed. 2004. Cities, War and Terrorism. Malden, MA: Blackwell Publishing. . 2009. “The Urban 'Battlespace'.” Theory, Culture \& Society 26 (7-8) (December 1): 278-288. doi:10.1177/0263276409349280.

- 2010. Cities Under Siege: The New Military Urbanism. 1st ed. Verso.

- 2012. "Olympics 2012 Security: Welcome to Lockdown London." The Guardian, March 12, sec. Sport. http://www.guardian.co.uk/sport/2012/mar/12/london-olympicssecurity-lockdown-london.

Guebert, Jenilee, and Shamir Tanna. 2010. "Economic Benefits of Hosting G8 and G20 Summits." G8 Information Center. June 14. http://www.g8.utoronto.ca/evaluations/factsheet/factsheet_ecobenefits.pdf.

Hall, Rodney Bruce, and Thomas J. Biersteker. 2002. The Emergence of Private Authority in Global Governance. Cambridge University Press.

Hope, Christopher. 2009. "1,000 CCTV Cameras to Solve Just One Crime, Met Police Admits." Telegraph.co.uk, August 25, sec. uknews. http://www.telegraph.co.uk/news/uknews/crime/6082530/1000-CCTV-cameras-to-solvejust-one-crime-Met-Police-admits.html.

Huysmans, Jef. 2004. "Minding Exceptions: The Politics of Insecurity and Liberal Democracy." Contemporary Political Theory 3: 321-341.

ISU Joint Intelligence Group. 2009. "2010 G8 Summit - ISU JIG Intelligence Report (Batch 2, JIG, M3551)”. Toronto Media Co-op. http://toronto.mediacoop.ca/story/download-g20papers/9197. 
Kennedy, Brendan, and Jesse Mclean. 2010. “Condo Behind Security Fence During G20 Summit." The Toronto Star, May 18. http://www.thestar.com/news/torontog20summit/article/810825--condo-behind-securityfence-during-g20-summit.

Kirton, John, Jenilee Guebert, and Shamir Tanna. 2010. "G8 and G20 Summit Costs”. University of Toronto: Munk School for Global Affairs. http://www.g8.utoronto.ca/evaluations/factsheet/factsheet_costs.pdf.

Krahmann, Elke. 2012. 'From 'Mercenaries' to 'Private Security Contractors': The (Re)Construction of Armed Security Providers in International Legal Discourses." Millennium - Journal of International Studies 40 (2) (January 1): 343-363. doi:10.1177/0305829811426673.

Leander, Anna. 2005a. "The Market for Force and Public Security: The Destabilizing Consequences of Private Military Companies." Journal of Peace Research 42 (5): 60522. . 2005b. "The Power to Construct International Security: On the Significance of Private Military Companies." Millennium: Journal of International Studies 33 (3): 803-825.

- 2010. "The Paradoxical Impunity of Private Military Companies: Authority and the Limits to Legal Accountability." Security Dialogue 41 (5) (October 1): 467-490. doi:10.1177/0967010610382108.

Lee, Jeff. 2009. "Security Firms Tap New Rule to Hire 5,000 Guards for 2010 Olympics." Vancouver Sun, April 18, Online edition.

http://www.vancouversun.com/business/Security+firms+rule+hire+guards+2010+Olympi cs/1510858/story.html.

Lefebvre, Henri. 1995. Writings on Cities. Translated by Eleonore Kofman and Elizabeth Lebas. 1st ed. Oxford: Wiley-Blackwell.

Lippert, R., and D. O’Connor. 2003. "Security Assemblages: Airport Security, Flexible Work, and Liberal Governance." Alternatives: Global, Local, Political 28 (3): 331-358.

Malleson, Tom, and David Wachsmuth, ed. 2011. Whose Streets?: The Toronto G20 and the Challenges of Summit Protest. Toronto: Between the LInes.

Marin, Andre. 2010. "Investigation into The Ministry of Community Safety and Correctional Services' Conduct in Relation to Ontario Regulation 233/10 Under the Public Works Protection Act: 'Caught in the Act'". Ombudsman Report. http://www.ombudsman.on.ca/Resources/Reports/Caught-in-the-Act.aspx?lang=en-CA.

McKiernan, Michael. 2012. “G20 Legal Probe Draining Toronto Police Fund.” Legal Feeds (Canadian Lawyer Magazine). http://www.canadianlawyermag.com/legalfeeds/678/G20legal-probe-draining-Toronto-police-fund.html.

McLean, Jesse. 2011. "G20 Private Security Firm Charged -.” The Toronto Star, April 1, online edition. http://www.thestar.com/news/article/967476--g20-private-security-firm-charged.

McMurtry, Roy. 2011. "Report of the Review of the Public Works Protection Act”. Ontario: Ministry of Community Safety and Correctional Services. http://www.mcscs.jus.gov.on.ca/stellent/groups/public/@mcscs/@www/@com/document s/webasset/ec088595.pdf.

Mertl, Steve. 2010. "Security Olympic Screening Assigned to Novices.” The Toronto Star Olympics. January 25. http://olympics.thestar.com/2010/article/755326--securityolympic-screening-assigned-to-novices. 
Moreau Emergency Management Consulting Corp, and Public Safety Canada. 2010. "Exercise Trillium Guardian 2010 GOC Confirmation Report (Batch 1, PCS, Moreau on EXTG)". Toronto Media Co-op. http://toronto.mediacoop.ca/story/download-g20-papers/9197.

Moreau, Richard. n.d. "Richard Moreau - Canada | LinkedIn." Linked-In. http://ca.linkedin.com/pub/richard-moreau/17/88b/a40.

Murphy, Christopher. 2007. “'Securitizing' Canadian Policing: A New Policing Paradigm for the Post 9/11 Security State?” The Canadian Journal of Sociology / Cahiers Canadiens de Sociologie 32 (4) (December 1): 449-475. doi:10.2307/20460665.

Ontario Provincial Police. 2010. "OPP Costs - 2010 G8 Summit and G20 Summit”. Standing Committee on Government Operations and Estimates. http://media.thestar.topscms.com/acrobat/6d/be/d4cf57504c09abfb848c7eef976a.pdf.

"PCO Emails (G20 Papers Batch 2, PCO, Documents PCO-01, PCO-03, \& PCO-04)." 2010. Toronto Media Co-op. http://toronto.mediacoop.ca/story/download-g20-papers/9197.

Radwanski, Adam. 2010. "A Timeline on the G20 Five-metre Rule That Didn't Exist - The Globe and Mail." The Globe and Mail, July 1, sec. Politics. http://www.theglobeandmail.com/news/politics/adam-radwanski/a-timeline-on-the-g20five-metre-rule-that-didnt-exist/article1626001/.

RCMP. 2010. "Briefing Report to the Commissioner (Batch 2, RCMP-J, B1321)". Toronto Media Co-op. http://toronto.mediacoop.ca/story/download-g20-papers/9197.

Revised Statutes of Ontario. 1990. Public Works Protection Act. http://www.elaws.gov.on.ca/html/statutes/english/elaws_statutes_90p55_e.htm.

Rider, David. 2010. “G20 ‘Fake Lake' Makes Its Debut.” The Toronto Star, July 23, online edition. http://www.thestar.com/news/gta/torontog20summit/article/827453--g20-fakelake-makes-its-debut.

Rigakos, George S, and David R Greener. 2000. "Bubbles of Governance: Private Policing and the Law in Canada." Canadian Journal of Law and Society 15: 145.

Rosenau, James N., and Ernst Otto Czempiel. 1992. Governance Without Government: Order and Change in World Politics. Cambridge University Press.

Ruskin, Brett. 2010. "Hundreds of Ottawa College Students to Provide Security at Vancouver Olympics." Ottawa Citizen, January 6, online edition.

http://www.ottawacitizen.com/sports/Hundreds+Ottawa+college+students+provide+secur ity+Vancouver+Olympics/2412354/story.html.

Rygiel, Kim. 2008. "The Securitized Citizen.” In Recasting the Social in Citizenship, edited by Engin Fahri Isin. Toronto: University of Toronto Press.

Schimmel, Kimberly S. 2012. "Protecting the NFL/ Militarizing the Homeland: Citizen Soldiers and Urban Resilience in Post-9/11 America." International Review for the Sociology of Sport 47 (3) (June 1): 338-357. doi:10.1177/1012690211433479.

Scholte, Jan Aart. 2005. Globalization, Second Edition: A Critical Introduction. 2nd ed. Palgrave Macmillan.

Security Industry Authority. n.d. "Olympic Security: Be Aware and Prepare." Security Industry Authority. http://www.sia.homeoffice.gov.uk/Pages/Olympics_Archive/olympics.aspx.

Shearing, C.D., and P.C. Stenning. 1981. "Modern Private Security: Its Growth and Implications." Crime and Justice: 193-245.

Sorenson, Kevin. 2011. "Report of the Standing Committee on Public Safety and National Security." 40th Parliament, 3rd Session. Ottawa: Parliament of Canada. http://publications.gc.ca/collections/collection_2011/parl/XC76-403-1-1-04-eng.pdf. 
Stancu, Henry. 2010. “Toronto’s \$124 Million G20 Police Budget Is Nearly 40 Per Cent Less According to Chief Bill Blair's 'fiscally Responsible' Figures. They Aimed High and Came in Lower." The Toronto Star, November 15.

http://www.thestar.com/news/crime/2010/11/15/toronto_g20_police_tab_39_under_budg et.html.

The Canadian Press. 2010. "Coalition Wants G20 'Political' Prisoners Released.” CTV.ca. July 5. http://toronto.ctv.ca/servlet/an/local/CTVNews/20100705/g20-arrests-rights-inquiryprisoners-100705/20100705/?hub=TorontoNewHome.

Thobani, Sunera. 2004. "Exception as Rule: Profile of Exclusion." Signs: Journal of Women in Culture and Society 29 (2) (January): 597-600. doi:10.1086/378569.

Toronto Police Services Board. 2011. "Minutes of the Public Meeting of the Toronto Police Services Board.” Toronto Police Services Board. February 3. http://www.tpsb.ca/FS/Docs/Minutes/2011/orderby,4/page,2/.

Treasury Board of Canada. 2011. "G8/G20 Horizontal Initiative (Royal Canadian Mounted Police - Supplementary Tables)." Treasury Board of Canada. http://www.tbssct.gc.ca/dpr-rmr/2010-2011/inst/rcm/st-ts09-eng.asp.

Warmington, Joe. 2010. “G20 Security Firm Contract Raises Questions.” Toronto Sun, July 26. http://www.torontosun.com/news/columnists/joe_warmington/2010/07/26/14836151.htm 1 .

Waterloo Region Police Service. 2010. "G20 Face to Face Front Line Officer Training." Toronto Media Co-op. http://toronto.mediacoop.ca/story/download-g20-papers/9197.

Yang, Jennifer. 2010a. "Downtown to Become a Fortress for G20 Summit." Toronto Star, March 19. http://www.thestar.com/news/gta/article/773133--downtown-to-become-a-fortressfor-g20-summit.

—. 2010b. "Just Being Near the G20 Security Zone Can Get You Arrested." The Toronto Star, June 25. http://www.thestar.com/news/torontog20summit/article/828498--justbeing-near-the-g20-security-zone-can-get-you-arrested.

Zack, Trevor. 2010. "Input Needed: Media Call re:G20 Fence (to Cara Thompson) (Batch 1 PCO-03)”, June 30. http://toronto.mediacoop.ca/story/download-g20-papers/9197. 